Mgr Joanna Sikora, https://orcid.org/0000-0003-1114-4934

Akademia Pedagogiki Specjalnej

im. Marii Grzegorzewskiej

\title{
Postawy rodzicielskie a wypalenie rodzicielskie. Mediacyjna rola aleksytymii, depresji \\ i podejmowanych strategii radzenia sobie ze stresem
}

\author{
Parental attitudes and parental burnout. The mediating role of \\ alexithymia, depression and stress coping strategies
}

https://doi.org/10.34766/fetr.v45i1.702

\begin{abstract}
Abstrakt: Cel: Celem badania była analiza związku między wypaleniem rodzicielskim a postawami rodzicielskimi z uwzględnieniem mediacyjnej roli aleksytymii, depresji oraz podejmowanych strategii radzenia sobie ze stresem. Postawy rodzicielskie określone na wymiarach: akceptacja, autonomia, wymagania i niekonsekwencja mają związek z poziomem wypalenia rodzicielskiego wobec własnych dzieci. Przyjęto, iż ważnym czynnikiem sprzyjającym jest aleksytymia, depresja oraz styl radzenia sobie ze stresem skoncentrowany na emocjach.

Metoda: Badanie przeprowadzono z udziałem 112 rodziców $(\mathrm{M}=39,16 ; \mathrm{SD}=5,39)$ posiadających dzieci $\mathrm{w}$ wieku od 3 do 15 lat. W celu weryfikacji hipotez badawczych użyto następujących kwestionariuszy: Kwestionariusz Wypalenia Rodzicielskiego (Parental Bournout Assessment, PBA); Kwestionariusz do pomiaru aleksytymii (Toronto Alexithymia Scale, TAS-20); Kwestionariusz Retrospektywnej Oceny Postaw Rodziców (Parental Bonding Questionnaire, KPR-Roc), Skala Depresji Becka (Beck Depression Scale, BDI), Kwestionariusz Radzenia Sobie w Sytuacjach Stresowych (Coping Inventory for Stessful Situations, CISS).

Rezultaty: W wyniku przeprowadzonych analiz statystycznych wykazano związek pomiędzy postawą rodzicielską matki a wypaleniem rodzicielskim. Ponadto stwierdzono istotną zależność aleksytymii, depresji oraz stylów radzenia sobie ze stresem z wypaleniem rodzicielskim. Czego następstwem była analiza mediacyjnego wpływu wspomnianych zmiennych na relację pomiędzy retrospektywnymi postawami rodzicielskimi ze strony matek a wypaleniem rodzicielskim. Analizę mediacji wielokrotnej wykonano przy pomocy niestandardowego makro do SPSS PROCESS (Hayes, 2018), która okazała się być istotna statystycznie dla wymagań, niekonsekwencji, a także autonomii i akceptacji ze strony Matki. Istotnymi mediatorami w każdym modelu były aleksytymia, depresja oraz styl radzenia sobie ze stresem skoncentrowany na emocjach. Podobnych zależności nie wykazano w odniesieniu do relacji z ojcem.

Konkluzje: Przeprowadzone badanie wskazuje na istnienie silnych związków między postawą rodzicielską matki a wypaleniem rodzicielskim wobec własnych dzieci. Aleksytymia, depresja i styl radzenia sobie ze stresem skoncentrowany na emocjach zwiększają ryzyko wystąpienia wypalenia rodzicielskiego.
\end{abstract}

Słowa kluczowe: aleksytymia, depresja, postawy rodzicielskie, styl radzenia sobie ze stresem, wypalenie rodzicielskie

Abstract: Aim: The aim of the study was to analyse the relationship between parental burnout and parental attitudes taking into account the mediating role of alexithymia, depression and coping strategies. Parental attitudes defined on the dimensions of acceptance, autonomy, demands and inconsistency are related to the level of parental burnout towards own children. Alexithymia, depression and an emotion-focused coping style were assumed to be important contributory factors. 
Method: The study was conducted with 112 parents $(\mathrm{M}=39.16$; $\mathrm{SD}=5.39)$ with children aged 3 to 15 years. The following questionnaires were used to verify the research hypotheses: Parental Burnout Assessment Questionnaire (PBA); Toronto Alexithymia Scale (TAS-20); Retrospective Parental Bonding Questionnaire (KPR-Roc), Beck Depression Scale (BDI), Coping Inventory for Stressful Situations (CISS).

Results: Statistical analyses revealed a relationship between mother's parenting attitude and parental burnout. Furthermore, alexithymia, depression and coping styles were found to be significantly related to parental burnout. What followed was an analysis of the mediating effect of the aforementioned variables on the relationship between retrospective parenting attitudes on the part of mothers and parental burnout. A multiple mediation analysis was performed using a custom macro for SPSS PROCESS (Hayes,2018), which was found to be statistically significant for demands, inconsistency, and autonomy and acceptance on the part of the mother. Significant mediators in each model were alexithymia, depression, and emotion-focused coping style. Similar relationships were not demonstrated for the relationship with the father.

Conclusions: The study indicates that there are strong relationships between mother's parenting attitudes and parental burnout towards their own children. Alexithymia, depression and emotionfocused coping style increase the risk of parental burnout.

Keywords: alexithymia, depression, parenting attitudes, coping styles, parenting burnout

\section{Wprowadzenie teoretyczne}

Wypalenie rodziców jest unikalnym i specyficznym dla danego kontekstu zespołem wynikającym z trwałej ekspozycji na chroniczny stres rodzicielski (Roskam i współpr., 2017; Mikolajczak i współpr., 2018). Pierwszym i głównym symptomem jest przytłaczające zmęczenie związane z rodzicielską rolą: rodzice czują się zmęczeni, gdy rano wstają i muszą zmierzyć się z nowym dniem; czują się emocjonalnie wyczerpani do tego stopnia, że ich myślenie o sobie jako rodzicu sprawia, że mają poczucie dojścia do kresu swojej wytrzymałości. Drugim symptomem jest emocjonalne dystansowanie się od własnych dzieci: wyczerpani rodzice coraz mniej angażują się w rodzicielstwo i relacje z dziećmi; interakcje są ograniczone do aspektów funkcjonalnych i instrumentalnych kosztem aspektów emocjonalnych. Trzecim symptomem jest utrata osiągnięć w rodzicielskiej roli: rodzice mają dość rodzicielstwa, nie mogą już dłużej pełnić roli ojca i matki i nie lubią przebywać ze swoimi dziećmi (Roskam i współpr., 2018). Zjawisko wypalenia rodzicielskiego jest specyficznym zespołem wynikającym z trwałej ekspozycji na chroniczny stres związany z macierzyństwem lub ojcostwem. Każdy rodzic doświadcza bardzo interesującego paradoksu, który polega na tym, że rodzicielstwo jest jedną z najbardziej energochłonnych i jednocześnie jedną z dających najwięcej energii aktywnością życiową. W szerszym rozumieniu istnieje równowaga między zasobami i ich rozwojem, a wymaganiami oraz ograniczeniami związanymi z pełnieniem roli rodzica. Problem pojawia się wówczas, gdy wymagania, a tym bardziej ograniczenia przewyższają uzyskiwane zasoby lub powodują ich wyniszczanie. Możemy wtedy wnioskować, że mamy do czynienia z procesem zmęczenia psychicznego lub wypalenia rodzicielskiego. 


\section{Teoretyczne wprowadzenie do badań}

\subsection{Wypalenie rodzicielskie - analiza pojęcia i koncepcji}

Pojęcie wypalenia rodzicielskiego wiąże się z koncepcją wypalenia zawodowego i zostało wprowadzone po raz pierwszy przez Freudenbergera oraz Maslach i Jackson. Autorzy ci zaobserwowali pewne podobieństwa między zawodowym wyczerpaniem a trudnościami doświadczanymi przez dorosłych $\mathrm{w}$ pełnionych przez siebie rolach rodzicielskich (Freudenberger, 1974; Maslach i Jackson, 1981; za: Lebert-Charron, Dorard, Boujut, Wendland, 2018).

Pierwsze wzmianki w literaturze na temat wypalenia rodziców pochodzą z 1983 roku. Zauważono wówczas, że rodzicielstwo może doprowadzić do wyczerpania w takim stopniu, że można je nazwać wypaleniem. Rodzice, którzy najbardziej są podatni na zjawisko wypalenia to ci, którzy najbardziej oczekiwali rodzicielstwa, którzy dają z siebie wszystko, czyli nadmiernie zaangażowani i nadgorliwi rodzice (za: Roskam i współpr., 2018). Również Pines i Aronson (1988) uważali, że wypalenie wystąpić może we wszystkich sferach, które dają ludziom poczucie sensu. Wykazali, że rodzicielstwo jest złożoną i stresującą aktywnością. Dzieci nadają sens życiu rodziców, stąd wniosek, że rodzicielstwo powinno być prawdopodobnym predyktorem do wypalenia.

W Europie wypalenie rodzicielskie zaczęło pojawiać się w badaniach w 2000 roku. W 2007 roku Norberg ocenił wypalenie za pomocą kwestionariusza Shirom-Melamed Burnout Questionnaire (SMBQ) wśród 24 matek i 20 ojców dzieci z guzem mózgu i porównał ich wyniki z wynikami rodziców dzieci zdrowych. Wyniki wypalenia matek w pierwszej grupie były znacznie wyższe niż w drugiej, natomiast wśród ojców różnica nie była istotna. W 2010 roku badanie zostało powtórzone na grupie 252 rodziców dzieci z cukrzycą typu 1 i grupie 38 rodziców dzieci z chorobą jelit. Wyniki porównano do 124 losowo wybranych rodziców zdrowych dzieci. Uzyskane wnioski były podobne do tych otrzymanych w pierwszym badaniu - poziom wypalenia matek dzieci chorych był znacznie wyższy niż matek dzieci zdrowych, natomiast wśród ojców nie było istotnej statystycznie różnicy (za: Roskam i współpr., 2018).

Podobne wyniki otrzymywano w kolejnych badaniach (Basaran i współpr., 2013). Rodzice dzieci z mózgowym porażeniem dziecięcym częściej doświadczają objawów wypalenia rodzicielskiego niż rodzice dzieci zdrowych. Natomiast szwedzkie badania pokazują, iż 34\% rodziców dzieci, które przeszły przeszczep komórek macierzystych zgłasza objawy wypalenia (Riva i współpr., 2014). W kolejnym badaniu rodziców dzieci z zaburzeniami rozwoju, przeprowadzonym przez Srinivasana Venkatesana oraz Reubena Thomasa Varghesea (2013), porównano syndrom wypalenia macierzyństwem w grupie 
matek dzieci z autyzmem i upośledzeniem słuchu. Wyniki badania wskazują na znacznie wyższy poziom wypalenia macierzyństwem u matek dzieci z autyzmem $(\mathrm{N}=30 ; \mathrm{M}=90.03$; $\mathrm{SD}=8.06 ; 85.74 \%)$ niż u matek dzieci z zaburzeniami słuchu ( $\mathrm{N}=30 ; \mathrm{Me}=67.0 ; \mathrm{SD}=15.94$; 63.81\%) (Varghese, Venkatesan, 2013).

Do ciekawych wniosków doszli Van Bekel, Van Engen i Petersa (2018). Wyniki ich badań wskazują, iż mężczyźni odnotowują wyższy poziom wypalenia rodziców. Zjawisko dotyczy szczególnie prezentowanego dystansu emocjonalnego i zmniejszenia osobistych osiągnięć w zakresie działań rodzicielskich oraz wypełniania rodzicielskich obowiązków. Badanie przeprowadzone na 304 francuskojęzycznych matkach w populacji ogólnej przy użyciu The Perceived Stress Scale (PSS), The Maslach Burnout Inventory Adapted to Parenthood (MBI-P), The Hospital Anxiety and Depression Scale (HADS), The Parenting Stress Index - Short-Form (PSI-SF) oraz Ways of Coping Checklist (WCC-R) wskazują na czynniki ryzyka wypalenia macierzyństwem. Okazuje się, iż bycie aktywnym zawodowo jest negatywnie powiązane z wypaleniem matki; zatrudnione matki czują się mniej wyczerpane emocjonalnie niż gospodynie domowe, czyli bezrobotni rodzice są bardziej narażeni na ryzyko wypalenia. Zadowolenie z pracy ma pozytywny wpływ na zadowolenie z życia. Oprócz zatrudnienia w pełnym wymiarze czasu pracy, również życie bez partnera oraz styl radzenia sobie skoncentrowany na zadaniu negatywnie korelują $\mathrm{z}$ wypaleniem matki. Zaskakujące okazują się wyniki wskazujące, iż samotne matki rzadziej doświadczają wypalenia macierzyństwem. Jednak może to wynikać z faktu, iż jako kobiety samotnie wychowujące swoje dzieci posiadają silną sieć wsparcia społecznego oraz mogą być mniej wyczerpane emocjonalnie, gdyż nie doświadczają niezadowolenia i wyzwań związanych z życiem we dwoje. I odwrotnie - depresja, lęk i wysoki poziom rodzicielskiego stresu korelują pozytywnie z wypaleniem macierzyństwem. Wysoki poziom depresji matek jest związany z wysokim poziomem wyczerpania emocjonalnego i depersonalizacji. Natomiast wysoki poziom lęku koreluje z wysokim poziomem wyczerpania emocjonalnego. Badanie wskazuje również na związek stresu z wysokim wyczerpaniem emocjonalnym i niskimi osobistymi osiągnięciami matek (Lebert-Charron, Dorard, Boujut, Wendland, 2018).

W 2017 roku Roskam, Raes i Mikolajczak dostarczyły wstępnych dowodów na poparcie istnienia wypalenia rodziców. Najpierw zaadaptowały Maslach Burnout Inventory (MBI) tak, aby wszystkie pozycje zostały jednoznacznie powiązane $\mathrm{z}$ kontekstem rodzicielskim. W wyniku przeprowadzonego badania walidacyjnego uzyskano inwentarz (PBI), będący miarą wypalenia rodzicielskiego, obejmujący trzy czynniki: wyczerpanie w roli rodzicielskiej, dystans emocjonalny od własnych dzieci oraz utratę skuteczności rodzicielskiej i spełnienia. Najnowsze naukowe doniesienia podkreślają, że wypalenie rodziców podobnie, jak wypalenie zawodowe jest specyficznym syndromem, który dotyczy nie tylko matek, ale także ojców (Roskam, Raes, Mikolajczak, 2017). Badanie przeprowadzone przy użyciu Inwentarza Wypalenia Rodzicielskiego (PBI) składającej się 
z 22 pozycji wskazuje, że podobnie, jak wypalenie zawodowe, wypalenie rodziców ma postać trójwymiarowego zespołu obejmującego emocjonalne wyczerpanie, dystans emocjonalny oraz (niskie) osobiste osiągnięcia (Roskam, Raes, Mikolajczak, 2017).

Badanie przeprowadzone przez Mikołajczak i współpr. (2018) na próbie 1551 rodziców dowiodło, że wypalenie rodziców ma szkodliwe dla nich konsekwencje. Zgodnie z modelem opracowanym przez autorki wypalenie uznać można za zaburzenie związane ze stresem, które jest wynikiem braku równowagi między ryzykiem a zasobami. Gdy tylko równowaga opiera się na negatywnej stronie (tj. ryzyko przeważa nad zasobami) rodzic zaczyna doświadczać większości objawów wypalenia każdego dnia. Stąd zostały wyodrębnione czynniki ryzyka jako czynniki, które znacznie zwiększają stres rodzicielski. Przykładami takich czynników zwiększających stres są: rodzicielski perfekcjonizm, unikanie przywiązania, niska inteligencja emocjonalna, nieefektywne praktyki wychowawcze, niezliczone obowiązki rodzicielskie i obowiązki domowe, brak wsparcia ze strony partnera, brak wsparcia zewnętrznego (wsparcie dla rodziny, żłobki itp.). Natomiast wśród zasobów i czynników działających ochronnie autorki wymieniają: rodzicielskie samozadowolenie, wysoką inteligencję emocjonalną, skuteczne praktyki wychowawcze, czas na wypoczynek, pozytywne wzorce, wsparcie zewnętrzne itp. (Mikolajczak, Roskam, 2018).

\subsection{Style przywiązania a wypalenie rodzicielskie}

John Bowlby (1973) podkreślał kluczową rolę związku pomiędzy dzieckiem a rodzicem dla jego prawidłowego rozwoju, zwłaszcza obszaru związanego z emocjami i ich regulacją. Zdolność do tworzenia bliskich relacji z wybranymi osobami obecna jest już we wczesnych etapach rozwoju człowieka. Styl przywiązania rozumiany jest jako stopień poczucia zaufania i bezpieczeństwa w związkach międzyludzkich. Kształtuje się w pierwszych miesiącach życia i ma swoje odniesienie w zachowaniu i dokonywaniu życiowych wyborów (Liberska, Suwalska, 2011). Mary Ainsworth (1989) w swoich pracach usystematyzowała wzory przywiązania dzieląc je na bezpieczne i pozabezpieczne (lękowoambiwalentny, lękowo-unikający). W odniesieniu do teorii więzi, zaburzenia występujące $\mathrm{w}$ relacji przywiązaniowej skutkują obniżeniem zdolności do tworzenia bezpiecznych relacji przywiązania w życiu dorosłym oraz pojawieniem sie różnego rodzaju zaburzeń emocjonalnych (Enns, Cox, Clara, 2002). Jako jeden z czynników ryzyka wystąpienia wypalenia rodzicielskiego wskazuje się podwyższony poziom lęku u rodzica, a także osobowość z dominującą cechą neurotyczności (Alarcon, Eschleman, Bowling, 2009). Co warte zauważenia, badanie Smith i współpr. (2015) wskazuje, że u osób prezentujących lękowy styl przywiązania, biologiczna odporność na sytuacje stresową jest znacznie osłabiona. Niepowodzenia doświadczane w relacji przywiazaniowej staja sie، źródłem lęku przed odrzuceniem i bliskością emocjonalną wobec innych ludzi (Gillath, Shaver, 2007). 
Takie podejście może skutkować znacznym osłabieniem zdolności do tworzenia więzi z dzieckiem i satysfakcji z pełnienia satysfakcjonującej roli rodzicielskiej.

\subsection{Aleksytymia, depresja i wypalenie rodzicielskie}

Istnieje wiele przesłanek wskazujących na związek pomiędzy obniżoną zdolnością do rozpoznawania (wskaźnik psychicznej reprezentacji emocji), wyrażania emocji (wskaźnik behawioralny) oraz rozumienia sygnałów płynących z ciała (wskaźnik fizjologiczny) a pozabezpiecznymi stylami przywiązania (Jones i współpr., 2014). Termin „aleksytymia” używany jest obecnie głównie do opisania problemów związanych z przetwarzaniem poznawczym pobudzenia emocjonalnego, czyli przede wszystkim trudności związanych z regulacją emocji i rozumieniem fizjologicznych następstw emocji (Zdankiewicz-Ścigała, Sikora, Ścigała, 2018). Opiekunowie dzieci, którzy wykazują znaczną trudność w wyrażaniu swoich emocji, mają jednocześnie deficyty w zakresie konstruktywnych form radzenia sobie z emocjami dziecka. W rezultacie doprowadzić to może do nieefektywnego rozpoznawania i odpowiedniego pokierowania emocjonalnym rozwojem dziecka (Bagby, Taylor, 2000). Badania wskazują, że podwyższony poziom aleksytymii jest związany z niską samooceną (Masoumeh, Alavinezhad, 2016; Unal, 2004) oraz pozabezpiecznym przywiązaniem opartym na lękowo-unikającym wzorcu (Pikardi, Toni, Caroppo, 2005). Wszystkie te czynniki mogą podwyższać ryzyko wystąpienia rodzicielskiego wypalenia. W kryzysowych sytuacjach dochodzi do aktywowania posiadanych stylów więzi. Osoby z pozabezpiecznym stylem przywiązania mają wyższy poziom aleksytymii i mają tendencję do rozwoju zaburzeń emocjonalnych (Zdankiewicz-Ścigała, Sikora, Ścigała, 2018). Wyniki badań nad związkiem stylów przywiązania sprzyjających rozwojowi zaburzeń psychicznych są zgodne z przewidywaniami teorii przywiązania Bowlby'ego. Niedostateczne zaangażowanie rodzica $\mathrm{w}$ relacje $\mathrm{z}$ dzieckiem lub nadmierna jego opiekuńczość stanowią ważny predyktor do rozwinięcia się zaburzeń depresyjnych (Avagianou, Zafiropoulou, 2008).

\subsection{Radzenie sobie ze stresem, depresja a wypalenie rodzicielskie}

Badania Najmi i współpr. (2017) wśród matek dzieci z niepełnosprawnością odnoszą stres do transakcyjnego modelu Lazarusa i Folkman (Lazarus, Folkman, 1984) wskazują na pozytywne korelacje wypalenia macierzyństwem i stylu radzenia sobie skoncentrowanego na emocjach oraz negatywne wobec stylu skoncentrowanego na zadaniu. W ostatnim czasie pojawia się wiele nowych badań dotyczących kontekstu wypalenia rodzicielskiego. Badania belgijskie (Lebert-Charron, Dorard, Boujut, Wendland, 2018) pokazują, iż 8\% rodziców doświadcza wypalenia rodzicielskiego. Bycie rodzicem wiąże się ze znacznym obciążeniem psychicznym i fizycznym. Stres rodzicielski wynika z ciągłego dostosowywania się do dzieci 
oraz reagowania na ich wymagania i potrzeby. Na poziom odczuwanego stresu moga wpływać: wiek dziecka, liczba dzieci, monotonne codzienne obowiązki oraz łączenie obowiązków domowych i pracy zawodowej. Chroniczny stres natomiast może przyczyniać się do rozwoju syndromu wypalenia rodzicielskiego.

Podsumowując opisane wyżej doniesienia z wielu badań można przyjąć, że style więzi prezentowane przez rodziców będą wiązać się $\mathrm{z}$ jednej strony $\mathrm{z}$ aleksytymią i strategiami radzenia sobie ze stresem a z drugiej z obniżonym nastrojem czy depresją. Powiązane ze sobą czynniki stanowić będą predyktory dla wypalenia rodzicielskiego. Na wykresie nr 1 przedstawiono hipotetyczny model prezentujący postulowane zależności między zmiennymi.

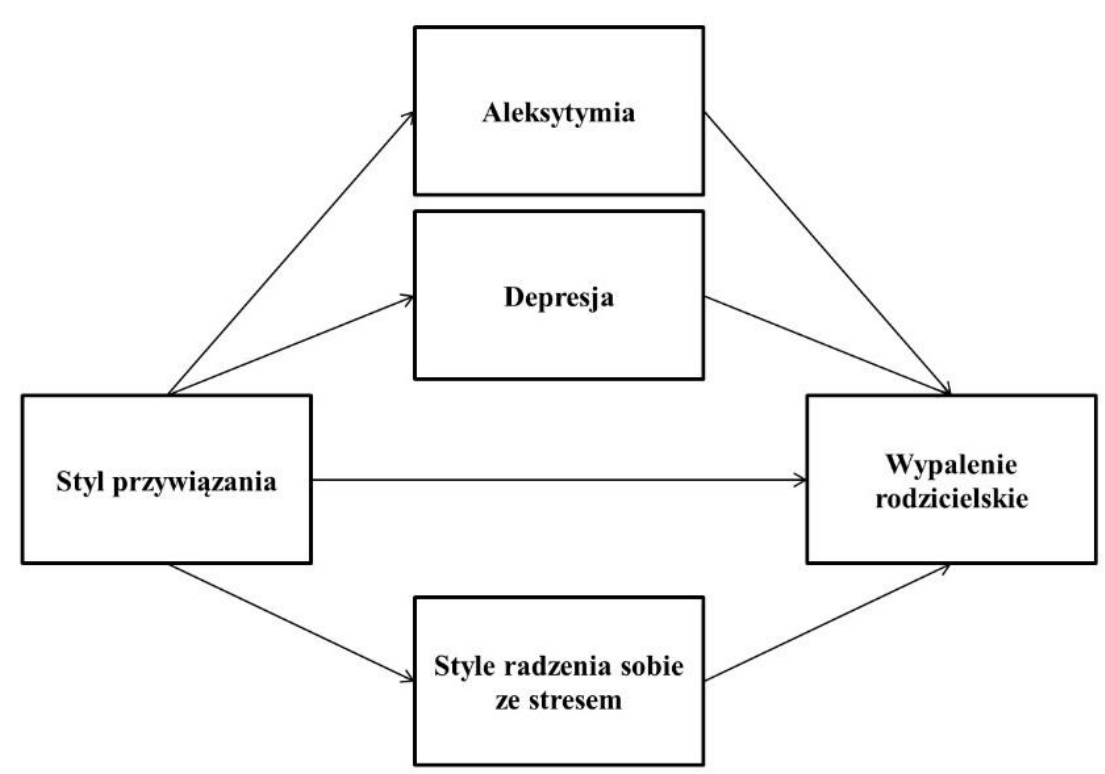

Wykres 1. Model teoretyczny (opracowanie własne)

Stąd głównym celem badań było sprawdzenie czy istnieje zależność między postawami rodzicielskimi a skłonnością do wypalenia rodzicielskiego wobec własnych dzieci oraz weryfikacja tego, czy aleksytymia, depresja i podejmowane strategie radzenia sobie ze stresem pełnią rolę pośredniczącą $\mathrm{w}$ tej zależności. Zgodnie $\mathrm{z}$ ustaleniami teoretycznymi przyjęto następujące hipotezy badawcze:

1) Im wyższy poziom akceptacji, autonomii i ochraniania rodziców tym niższy poziom wypalenia rodzicielskiego;

2) Im wyższy poziom niekonsekwencji i wymagań ze strony rodziców tym wyższy poziom wypalenia rodzicielskiego;

3) Stosowanie stylu skoncentrowanego na emocjach sprzyja wypaleniu rodzicielskiemu w przeciwieństwie do stylu skoncentrowanego na zadaniu 
4) Aleksytymia, depresja i style radzenia sobie ze stresem są istotnymi mediatorami relacji pomiędzy postawami rodzicielskimi a wypaleniem rodzicielskim.

\section{Badania własne}

\subsection{Uczestnicy badania}

W badaniu wzięło udział 112 osób w wieku od 29 do 54 lat $(\mathrm{M}=39,16$; SD = 5,39) byli to rodzice posiadający zdrowe dzieci w wieku od 3 do 15 roku życia. Wszystkie osoby badane były $\mathrm{w}$ stałych związkach małżeńskich i zamieszkiwały w województwie mazowieckim. W próbie nieznacznie większy odsetek stanowili mężczyźni (51,8\%). Pod względem poziomu wykształcenia dominowały osoby posiadające wyższe wykształcenie (58,9\%); pozostały procent stanowiły osoby z wykształceniem średnim. Uczestnicy badania otrzymali niezbędne informacje o przebiegu oraz celu badania. Przed wypełnieniem kwestionariuszy poproszono ich o podpisanie formularza świadomej zgody, zawierającego wszystkie niezbędne informacje odnośnie do badania oraz prawa przysługujące osobom biorącym w nich udział. Badanie zostało przeprowadzone $\mathrm{w}$ formie stacjonarnej.

\subsection{Materiał i metoda}

Kwestionariusz do pomiaru aleksytymii (TAS-20)Toronto Alexithymia Scale (Parker, et al., 1993) w polskim tłumaczeniu Ścigała, D. K., Zdankiewicz-Ścigała, E., Bedyńska, S., \& Kokoszka, A. (2020) użyto do zbadania poziomu aleksytymii. Oprócz ogólnego poziomu aleksytymii, kwestionariusz pozwala obliczyć osobne skale dla wymiarów: "trudności w werbalizowaniu uczuć”; "trudności w identyfikacji uczuć"; "operacyjny styl myślenia". Kwestionariusz składa się z 20 pozycji testowych. Każda pozycja ma pięciostopniową skalę Likerta (1-całkowicie się nie zgadzam; 2-częściowo się nie zgadzam się; 3-nie mam zdania; 4-częściowo się zgadzam; 5-całkowicie się zgadzam). Skala jest od 20 do 100 puntów. W odniesieniu do przeprowadzonego badania współczynnik a Cronbacha wynosi 0,84 dla wyniku ogólnego; 0,71 dla skali "trudności w werbalizowaniu emocji"; 0,79 dla skali „trudności z identyfikacją emocji”; 0,47 dla skali „operacyjnego stylu myślenia”.

Kwestionariusz Wypalenia Rodzicielskiego (PBA) Parental Burnout Assessment (Roskam et. al., 2018) w polskim opracowaniu Szczygieł D. i współ. (2020) został użyty do zbadania poziomu wypalenia rodzicielskiego. Kwestionariusz jest zbudowany z 23 pytań, służących do pomiaru czterech wymiarów wypalenia rodzicielskiego: wyczerpania, kontrastu, dystansu emocjonalnego i przemęczenia. Zadaniem osoby badanej, wypełniającej kwestionariusz, jest ustosunkowanie się do stwierdzeń, zaznaczając cyfrę na 
siedmiostopniowej skali najlepiej odpowiadającą częstotliwości jej uczuć (0-nigdy, 1-kilka razy $\mathrm{w}$ roku, 2-raz $\mathrm{w}$ miesiącu lub rzadziej, 3-kilka razy $\mathrm{w}$ miesiącu, 4-raz w tygodniu, 5-kilka razy $\mathrm{w}$ tygodniu, 6-codziennie. $\mathrm{W}$ odniesieniu do przeprowadzonego badania współczynnik a Cronbacha wynosi 0,96 dla wyniku ogólnego.

Kwestionariusz Retrospektywnej Oceny Postaw Rodziców (KPR-Roc) Parental Bonding Questionnaire - autorstwa Mieczysława Plopy (Plopa, 2008). Kwestionariusz służy do retrospektywnej oceny postaw rodzicielskich matki i ojca. Jest narzędziem samoopisowym, przeznaczonym do badania osób powyżej 20 roku życia. Osoba badana proszona jest o ustosunkowanie się do 50 twierdzeń dotyczących postaw i zachowań każdego z rodziców, tak jak zostały zapamiętane przez osobę badaną. Osoba badana proszona jest o ocenę twierdzeń na pięciopunktowej skali: a-zdecydowanie taki był i tak się zachowywał, b-raczej taki był i tak się zachowywał, c-mam wątpliwości, czy taki był i tak się zachowywał, d-raczej taki nie był i tak się nie zachowywał, e-zdecydowanie taki nie był i tak się nie zachowywał. Narzędzie pozwala na retrospektywna ocenę rodziców w zakresie pięciu postaw rodzicielskich: akceptacja / odrzucenie, wymagania, autonomia, niekonsekwencja, ochranianie. $\mathrm{W}$ odniesieniu do przeprowadzonego badania współczynnik a Cronbacha dla poszczególnych skal wynosi: wymagania-matka 0,88, wymagania-ojciec 0,86; akceptacjamatka 0,93, akceptacja-ojciec 0,93; autonomia-matka 0,87, autonomia-ojciec 0,88; niekonsekwencja-matka 0,90 , niekonsekwencja-ojciec 0,85 ; ochranianie-matka 0,82 , ochranianie-ojciec 0,79.

Skala Depresji Becka (BDI-II) Beck Depression Scale w polskiej adaptacji Łojek i Stańczak (2019) został użyty do zbadania poziomu depresji. Kwestionariusz jest zbudowany z 21 stwierdzeń dotyczących samopoczucia w ciągu ostatnich 7 dni. Zadaniem osoby badanej jest ustosunkowanie się do każdego stwierdzenia na czterostopniowej skali. Wyniki wskazują na wstępną ocenę nasilenia badanych symptomów. W odniesieniu do przeprowadzonego badania współczynnik a Cronbacha wynosi 0,92 dla wyniku ogólnego.

Kwestionariusz Radzenia Sobie w Sytuacjach Stresowych (CISS) Coping Inventory for Stressful Situations (N.S. Endler, J.D.A. Parker) w polskiej adaptacji P. Szczepaniaka, J. Strelaua i K. Wiśniewskiego (2005) został użyty do zbadania podejmowanych strategii radzenia sobie ze stresem. Kwestionariusz jest zbudowany z 48 stwierdzeń dotyczących różnych zachowań, jakie ludzie mogą podejmować w sytuacjach stresowych. Zadaniem osoby badanej, wypełniającej kwestionariusz, jest określenie na pięciostopniowej skali częstotliwości, z jaką podejmuje dane działanie w sytuacjach trudnych, stresowych. Wyniki określane są na trzech skalach: SSZ - styl skoncentrowany na zadaniu, SSE - styl skoncentrowany na emocjach, SSU - styl skoncentrowany na unikaniu. Ten ostatni styl może 
przyjmować dwie formy: ACZ - angażowanie się w czynności zastępcze i PKT poszukiwanie kontaktów towarzyskich. W odniesieniu do przeprowadzonego badania współczynnik a Cronbacha dla skali styl radzenia sobie ze stresem skoncentrowany na zadaniu wynosi 0,86, dla skali styl radzenia sobie ze stresem skoncentrowany na emocjach wynosi 0,91 , a dla skali styl radzenia sobie ze stresem skoncentrowany na unikaniu wynosi 0,77 .

\subsection{Wyniki}

Analizę statystyczną pozwalającą na przetestowanie postawionych hipotez przeprowadzono w programie IBM SPSS Statistics w wersji 25. Przy jego użyciu wykonano analizę podstawowych statystyk opisowych dzięki czemu możliwe było zbadanie kształtu rozkładów kolejnych mierzonych zmiennych. Hipotezy przetestowano przy użyciu szeregu analiz korelacji, ANOVA oraz analiz mediacji za pomocą makra PROCESS Hayes'a (2018). Za poziom istotności uznano klasyczny próg a $=0,05$. W tabeli 1 przedstawiono podstawowe statystyki opisowe dla analizowanych wskaźników. Dodatkowo wszystkie zmienne zbadano pod kątem posiadanego rozkładu na podstawie miar tendencji centralnych, rozproszenia a także testu Kołmogorowa-Smirnowa. Uzyskane wyniki pokazały, że jedynie w przypadku operacyjnego stylu myślenia uzyskany rozkład odbiegał nieznacznie od normalnego (wykazując cechy rozkładu leptokurtycznego).W pozostałych przypadkach rozkłady nie odbiegały od normalnego.

Tabela nr 1a. Podstawowe statystyki opisowe analizowanych wskaźników

\begin{tabular}{|l|c|c|c|c|c|}
\hline Dane & MIN & MAX & M & SE & SD \\
\hline Wiek & 29,00 & 54,00 & 39,16 & 0,51 & 5,39 \\
\hline Wypalenie rodzicielskie & & & & & \\
\hline Wypalenie rodzicielskie & 0,00 & 78,00 & 17,87 & 1,99 & 20,91 \\
\hline Styl przywiązania & & & & & \\
\hline Matka - akceptacja & 12,00 & 50,00 & 36,68 & 0,84 & 8,88 \\
\hline Ojciec - akceptacja & 10,00 & 50,00 & 34,07 & 0,94 & 9,79 \\
\hline Matka - wymagania & 11,00 & 46,00 & 27,46 & 0,82 & 8,63 \\
\hline Ojciec - wymagania & 10,00 & 41,00 & 25,89 & 0,76 & 7,89 \\
\hline Matka - autonomia & 17,00 & 50,00 & 36,10 & 0,72 & 7,61 \\
\hline Ojciec - autonomia & 10,00 & 47,00 & 34,28 & 0,72 & 7,45 \\
\hline Matka - niekonsekwencja & 10,00 & 45,00 & 23,54 & 0,85 & 8,95 \\
\hline Ojciec - niekonsekwencja & 10,00 & 40,00 & 24,39 & 0,76 & 7,85 \\
\hline
\end{tabular}


Tabela nr 1b. Podstawowe statystyki opisowe analizowanych wskaźników (cd.)

\begin{tabular}{|l|c|c|c|c|c|}
\hline Matka - ochrona & 15,00 & 47,00 & 32,02 & 0,71 & 7,53 \\
\hline Ojciec - ochrona & 10,00 & 40,00 & 25,74 & 0,65 & 6,75 \\
\hline Aleksytymia & & & & & \\
\hline Trudności w werbalizowaniu uczuć & 5 & 24 & 11,68 & 0,38 & 4,04 \\
\hline Trudności w identyfikacji uczuć & 7 & 30 & 14,79 & 0,53 & 5,60 \\
\hline Operacyjny styl myślenia & 10 & 28 & 18,52 & 0,39 & 4,14 \\
\hline Aleksytymia & 25 & 70 & 44,98 & 1,10 & 11,63 \\
\hline Depresja & 0,00 & 42,00 & 6,63 & 0,79 & 8,37 \\
\hline Style radzenia sobie ze stresem & & & & & 7,95 \\
\hline Styl skoncentrowany na zadaniu & 42,00 & 80,00 & 61,16 & 0,75 & 11,85 \\
\hline Styl skoncentrowany na emocjach & 20,00 & 70,00 & 38,71 & 1,12 & 7,96 \\
\hline Styl skoncentrowany na unikaniu & 22,00 & 60,00 & 43,07 & 0,75 & \\
\hline
\end{tabular}

W celu weryfikacji pierwszej hipotezy odnośnie do postaw rodzicielskich a wypalenia rodzicielskiego wykonano analizę korelacji liniowej $r$ Pearsona. Analiza uzyskanych rezultatów (Tabela $\mathrm{nr}$ 2) pozwala na stwierdzenie, że istnieje korelacja pomiędzy postawami matki a poziomem wypalenia wobec własnych dzieci. Im wyższa akceptacja ( $\mathrm{r}=-$ 0,354; $\mathrm{p}<0,001)$ i autonomia $(\mathrm{r}=-0,291 ; \mathrm{p}<0,001)$ ze strony matki tym niższy poziom wypalenia rodzicielskiego. Im wyższe wymagania $(r=0,253 ; p<0,001)$ i niekonsekwencja $(r=0,428 ; p<0,001)$ ze strony matki tym wyższy poziom wypalenia rodzicielskiego. Podobnych zależności nie wykazano w zakresie postaw ojca a wypalenia rodzicielskiego.

Tabela nr 2. Związek pomiędzy wypaleniem rodzicielskim a postawami rodzicielskimi Matki i Ojca

\begin{tabular}{|l|c|}
\hline & Wypalenie rodzicielskie \\
\hline Matka - akceptacja & $-0,354^{* *}$ \\
\hline Ojciec - akceptacja & 0,005 \\
\hline Matka - wymagania & $0,253^{* *}$ \\
\hline Ojciec - wymagania & 0,058 \\
\hline Matka - autonomia & $-0,291^{* *}$ \\
\hline Ojciec - autonomia & 0,008 \\
\hline Matka - niekonsekwencja & $0,428^{* *}$ \\
\hline Ojciec - niekonsekwencja & 0,050 \\
\hline Matka - ochrona & $-0,121$ \\
\hline Ojciec - ochrona & 0,186 \\
\hline
\end{tabular}

${ }^{*}-\mathrm{p}<0,05 ;{ }^{* *}-\mathrm{p}<0,001$ 
Weryfikując drugą z kolei hipotezę wykonano także analizę korelacji r Pearsona (Tabela $\mathrm{nr}$ 3). Okazało się, że aleksytymia $(\mathrm{r}=0,304 ; \mathrm{p}<0,001)$ i depresja $(\mathrm{r}=0,494 ; \mathrm{p}<0,001)$ są związane $\mathrm{z}$ wypaleniem rodzicielskim. Wykazano, że im wyższy poziom depresji i aleksytymii tym wyższy poziom wypalenia rodzicielskiego wśród badanych rodziców.

Tabela nr 3. Związek pomiędzy wypaleniem rodzicielskim a aleksytymią i depresją

\begin{tabular}{|l|c|}
\hline & Wypalenie rodzicielskie \\
\hline Trudności w werbalizowaniu uczuć & $0,200^{*}$ \\
\hline Trudności w identyfikacji uczuć & $0,266^{* *}$ \\
\hline Operacyjny styl myślenia & \\
\hline Aleksytymia & $0,299^{* *}$ \\
\hline Depresja & $0,304^{* *}$ \\
\hline *-p<0,05;**-p $<0,001$ & $0,494^{* *}$ \\
\hline
\end{tabular}

Weryfikując kolejną hipotezę odnośnie do związku pomiędzy stylami radzenia sobie ze stresem a wypaleniem rodzicielskim ponownie wykonano analizę korelacji liniowej r Pearsona. Uzyskane wyniki wskazują na ujemną korelację w zakresie stylu radzenia sobie ze stresem skoncentrowanym na zadaniu $(r=-0,414 ; \mathrm{p}<0,001)$ a poziomem wypalenia rodzicielskiego oraz dodatnia istotna zależność pomiędzy stylem radzenia sobie skoncentrowanym na emocjach $(r=0,467 ; \mathrm{p}<0,001)$ i unikaniu $(r=0,339 ; \mathrm{p}<0,001)$ a poziomem wypalenia rodzicielskiego.

Tabela nr 4. Związki pomiędzy strategiami radzenia sobie ze stresem a poziomem wypalenia rodzicielskiego - wartości współczynników korelacji r Pearsona

\begin{tabular}{|l|c|}
\hline Style & Wypalenie rodzicielskie \\
\hline Styl skoncentrowany na zadaniu & $-0,414^{* *}$ \\
\hline Styl skoncentrowany na emocjach & $0,467^{* *}$ \\
\hline Styl skoncentrowany na unikaniu & $0,339^{* *}$ \\
\hline
\end{tabular}

${ }^{*}-\mathrm{p}<0,05 ;{ }^{* *}-\mathrm{p}<0,001$ 
W celu weryfikacji ostatniej $\mathrm{z}$ hipotez badawczych wykonano bardziej zaawansowane analizy statystyczne. W pierwszej kolejności za pomocą niestandardowego makra Process (Hayes, 2018) przy użyciu wielokrotnej mediacji z użyciem metody Bootstrapingu i 95\% przedziałów ufności zbadano czy aleksytymia, depresja i style radzenia sobie ze stresem są mediatorami relacji pomiędzy postawami rodzicielskimi a wypaleniem rodzicielskim. Model mediacji dla relacji między wymaganiami ze strony matki a wypaleniem rodzicielskim jest istotny statystycznie $(F(8,101)=9,2124 ; p<0,001)$ i wyjaśnia $42 \%$ zmienności wyników wypalenia rodzicielskiego. Istotnymi mediatorami są trudność w identyfikowaniu emocji(a2;b2) 95\% CI [ -.22, -.01], depresja(a4;b4) 95\% CI [ .01, .20] i styl skoncentrowany na emocjach(a6;b6) 95\% CI [ .02, .23]. Czynnikami, które zwiększają podatność na wypalenie rodzicielskie są depresja i styl skoncentrowany na emocjach. Ponadto po wprowadzeniu mediatorów do modelu związek pomiędzy zmienną niezależną i zależną staję się nieistotny (Wykres nr 2).

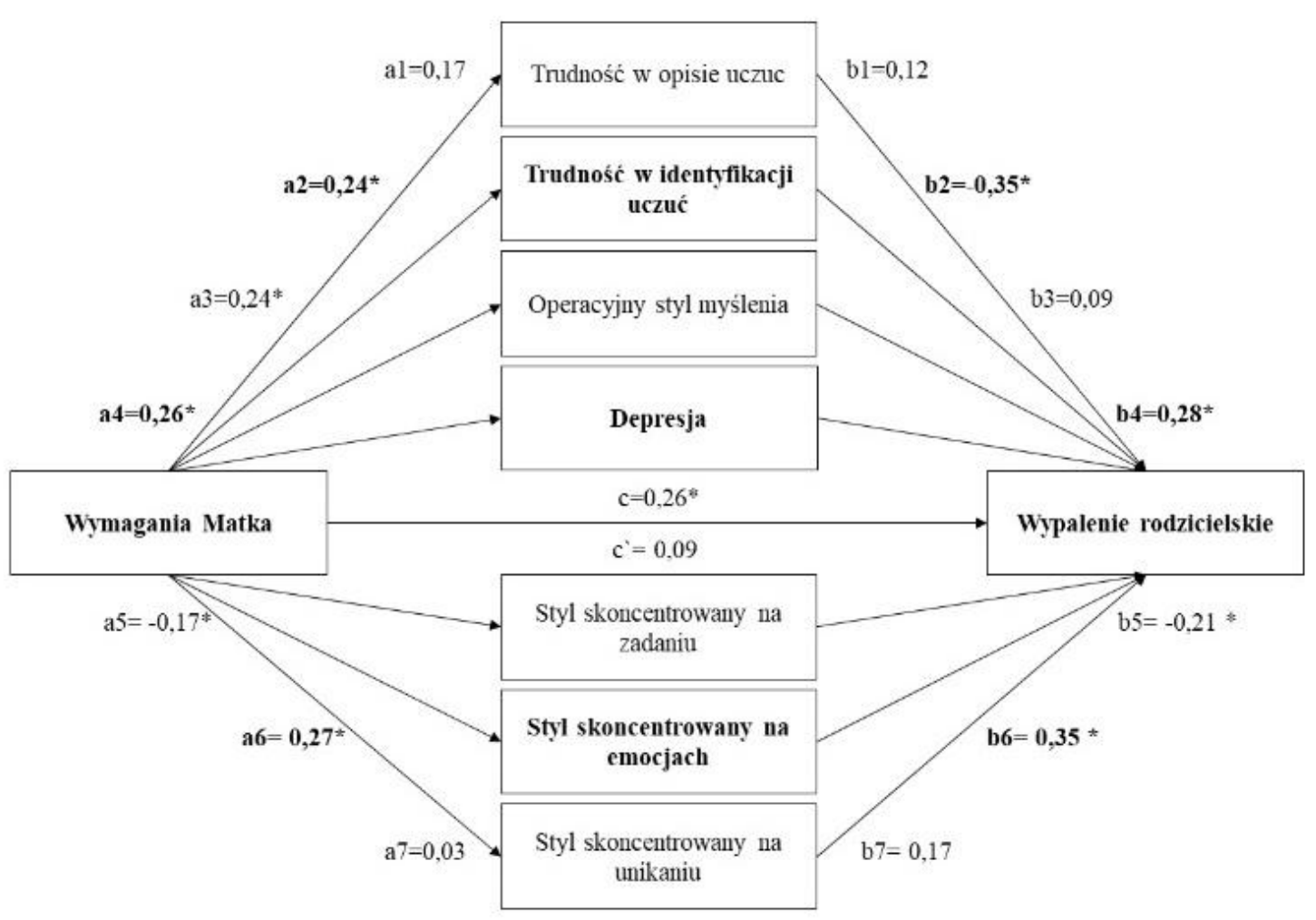

Wykres nr 2. Model zależności pomiędzy wymaganiami ze strony Matki a wypaleniem rodzicielskim z uwzględnieniem mediacyjnej roli aleksytymii, depresji i strategii radzenia sobie ze stresem 
W kolejnej analizie uwzględniono niekonsekwencję matki. Model mediacji dla relacji między niekonsekwencją ze strony matki a wypaleniem rodzicielskim jest istotny statystycznie $(F(8,101)=10,4373 ; p<0,001)$ i wyjaśnia $45 \%$ zmienności wyników wypalenia rodzicielskiego. Istotnymi mediatorami są trudności w identyfikowaniu emocji (a2;b2) 95\% CI [ -.25, -.02], depresja 95\%(a4;b4) CI [ .001, .24] i styl skoncentrowany na emocjach (a6,b6) 95\% CI [ .02, .25]. Czynnikami, które zwiększają podatność na wypalenie rodzicielskie są depresja i styl skoncentrowany na emocjach. Ponadto po umieszczeniu mediatorów w modelu związek pomiędzy niekonsekwencją matki a wypaleniem rodzicielskim zmniejsza się choć nadal jest znaczący (Wykres nr 3).

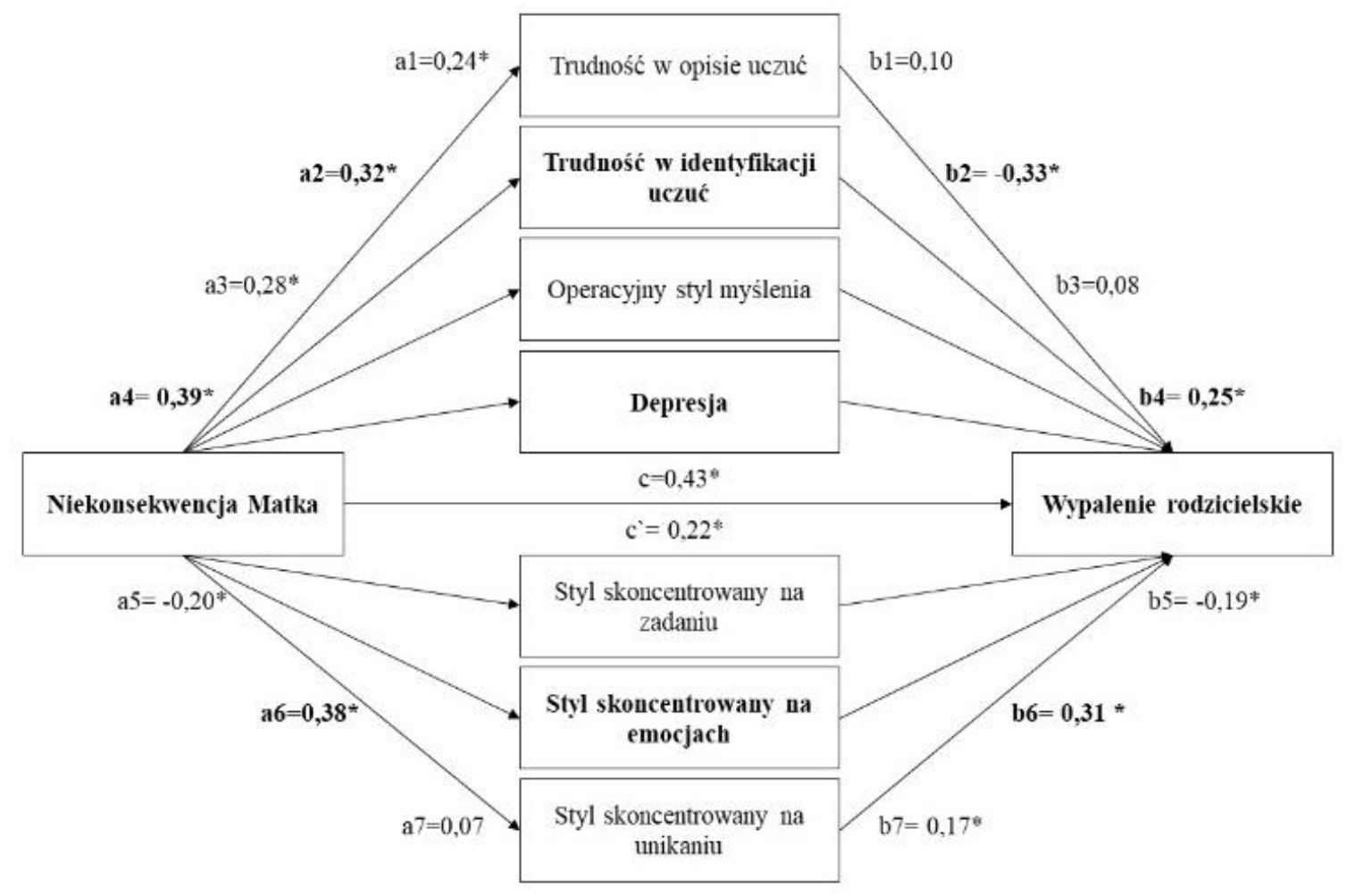

Wykres 3. Model zależności pomiędzy niekonsekwencją ze strony Matki a wypaleniem rodzicielskim z uwzględnieniem mediacyjnej roli aleksytymii, depresji i strategii radzenia sobie ze stresem

Do weryfikacji w kolejnym modelu wybrano akceptację ze strony matki. Model mediacji dla relacji między akceptacją ze strony matki a wypaleniem rodzicielskim jest istotny statystycznie $(\mathrm{F}(8,101)=10,9699 ; \mathrm{p}<0,001)$ i wyjaśnia 46\% zmienności wyników wypalenia rodzicielskiego. Ważnymi mediatorami są trudności w identyfikowaniu emocji (a2,b2) 95\% CI [ .02, .24]., depresja (a4,b4) 95\% CI [ -.18, -.003]. i styl skoncentrowany na 
emocjach (a6,b6) 95\% CI [ -.19, -.02]. Czynnikami, które zwiększają podatność na wypalenie rodzicielskie są depresja i styl skoncentrowany na emocjach. Ponadto po umieszczeniu mediatorów związek pomiędzy akceptacją ze strony matki a wypaleniem rodzicielskim jest nadal znaczący. Ponadto akceptacja ze strony matki jest czynnikiem chroniącym przed wypaleniem rodzicielskim (Wykres $\mathrm{nr}$ 4).

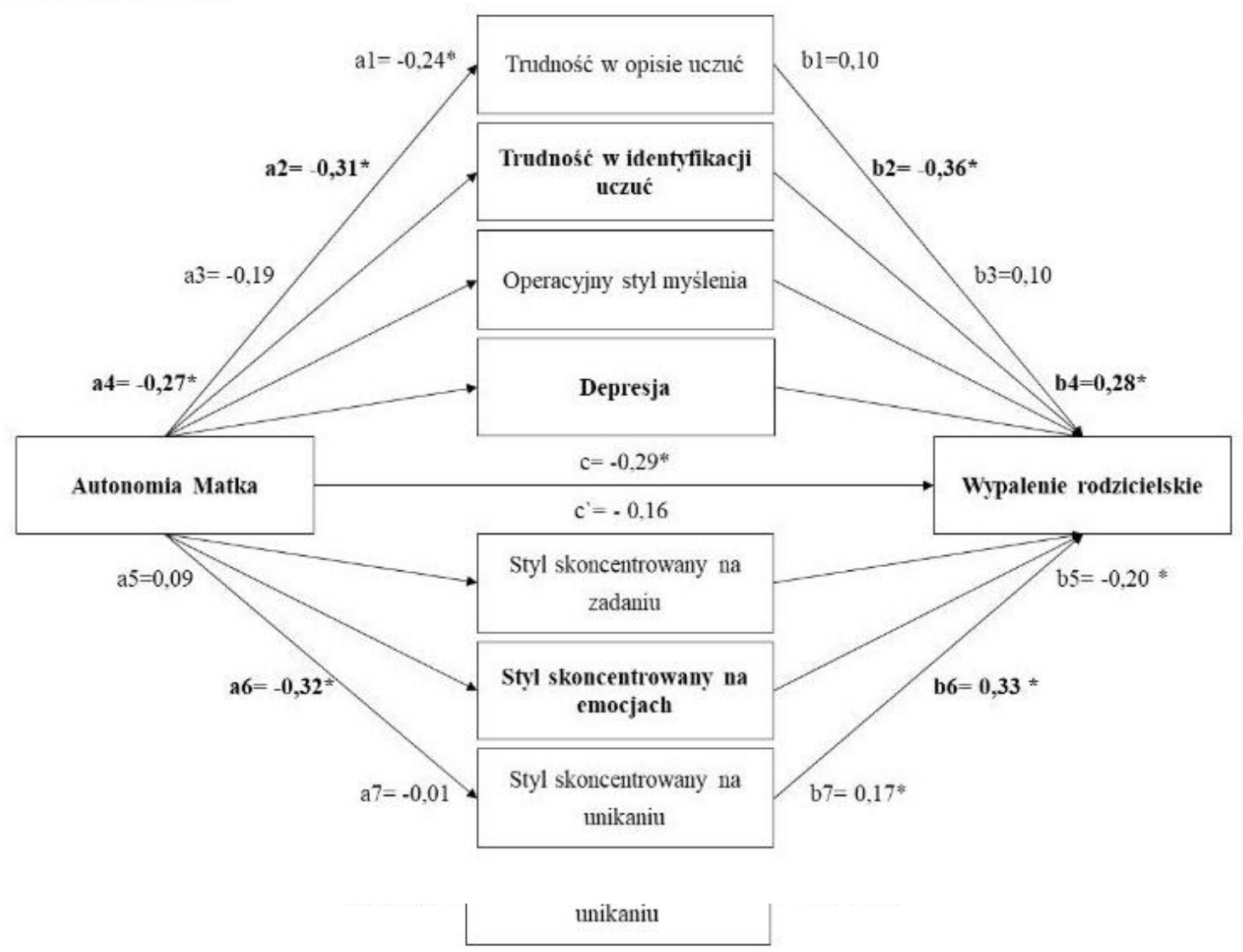

Wykres nr 4. Model zależności pomiędzy akceptacją ze strony Matki a wypaleniem rodzicielskim z uwzględnieniem mediacyjnej roli aleksytymii, depresji i strategii radzenia sobie ze stresem

W ostatnim kroku do analizy wybrano autonomię matki. Model mediacji dla relacji między autonomią matki a wypaleniem rodzicielskim jest istotny statystycznie $(\mathrm{F}(8,100)=9,5940 ; \mathrm{p}<0,001)$ i wyjaśnia $43 \%$ zmienności wyników wypalenia rodzicielskiego. Ważnymi mediatorami są trudności w identyfikowaniu emocji (a2,b2) 95\% CI [ .02, .26], depresja (a4,b4) 95\% CI [ -.18, -.004] i styl skoncentrowany na emocjach(a6,b6) 95\% CI [ -.23, .03]. Czynnikami, które zwiększają podatność na wypalenie rodzicielskie są depresja i styl skoncentrowany na emocjach. Ponadto po wprowadzeniu mediatorów do modelu związek pomiędzy autonomią matki a wypaleniem rodzicielskim nie jest już znaczący. Autonomia matki podobnie jak akceptacja ze strony matki jest czynnikiem chroniącym przed wypaleniem rodzicielskim (Wykres nr 5). 


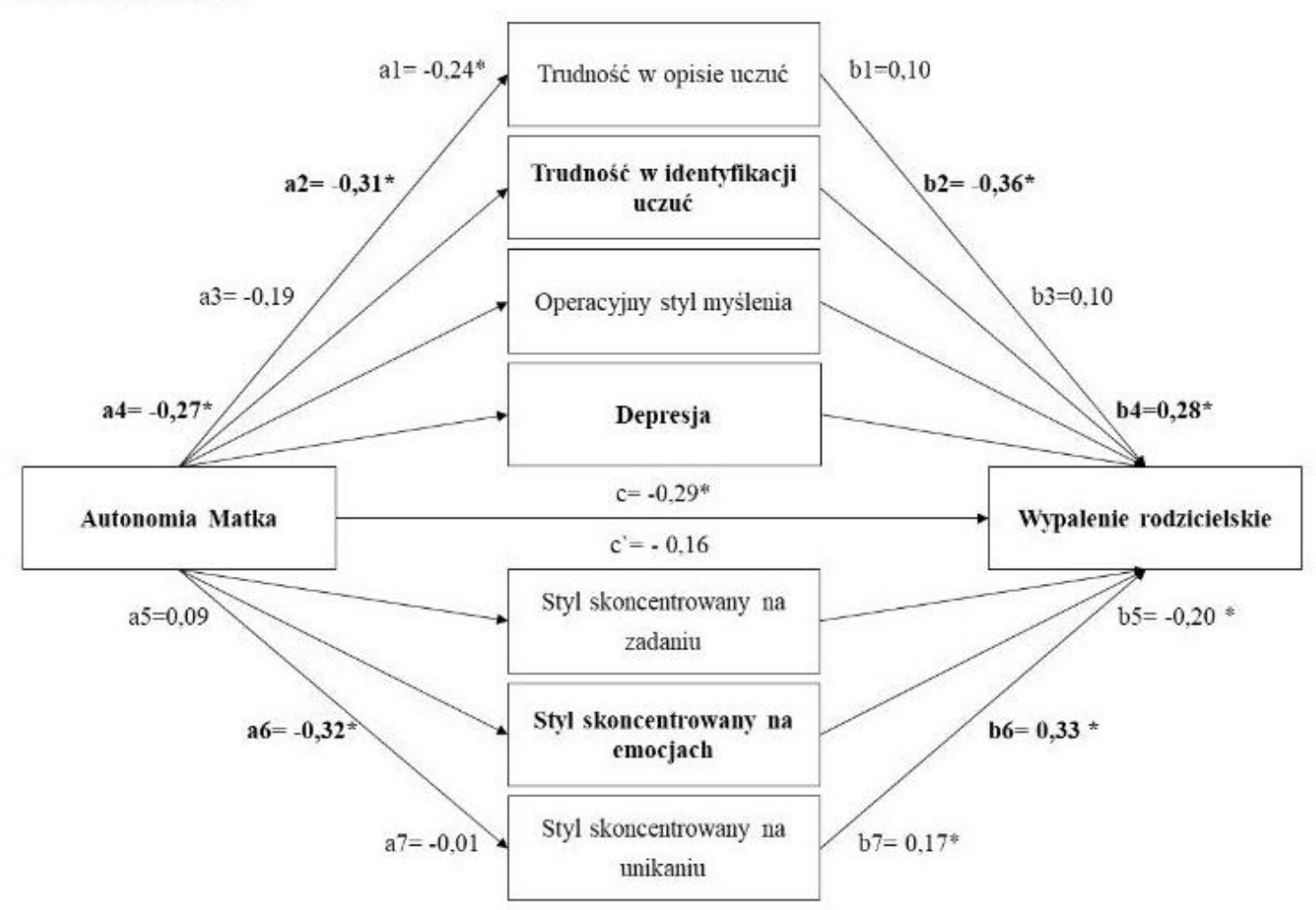

Wykres nr 5. Model zależności pomiędzy autonomią ze strony Matki a wypaleniem rodzicielskim z uwzględnieniem mediacyjnej roli aleksytymi, depresji i strategii radzenia sobie ze stresem

\section{Dyskusja wyników}

Podstawowe założenie, które przyjęto, przygotowując to badanie wiązało powstawanie wypalenia rodzicielskiego z postawami wobec własnych rodziców. Stąd celem badania była weryfikacja założeń dotyczących bezpośredniego związku między postawami rodzicielskimi określonymi na wymiarach: akceptacja, autonomia, wymagania, niekonsekwencja a poziomem wypalenia rodzicielskiego wobec własnych dzieci. Przyjęto, na bazie założeń teoretycznych omówionych wcześniej, że ważnym czynnikiem sprzyjającym zaburzeniom emocjonalnym jest aleksytymia. Ponadto czynnikami ryzyka występowania wypalenia rodzicielskiego jest depresja oraz styl radzenia sobie ze stresem skoncentrowany na emocjach. Badania przeprowadzono na populacji ogólnej, rodzicach posiadających zdrowe dzieci w wieku od 3 do 15 roku życia. Wśród badanych osób nie było osób leczonych psychiatrycznie, uzależnionych, ani posiadających dzieci chorujące na przewlekłe choroby. W wyniku przeprowadzonych analiz statystycznych wykazano, że postawy rodzicielskie matek wpływają na aktualne zachowania dorosłego człowieka. Dla rozwoju wypalenia rodzicielskiego znaczenie ma niekonsekwencja i wymagania ze strony matki. Natomiast akceptacja i autonomia stanowią czynniki ochronne. Nie zauważono takich zależności w zakresie postaw ojca a poziomem wypalenia rodzicielskiego. 
W każdej z przeprowadzonych analiz wykazano, że aleksytymia, depresja i styl radzenia sobie ze stresem skoncentrowany na emocjach są istotnymi czynnikiem wzmacniającym poziom wypalenia rodzicielskiego. Aleksytymia wiąże się ze znacznymi zaburzenia wynikającymi z poznawczych zniekształceń w sferze doznawania, interpretacji oraz reakcji w sytuacjach emotogennych. Poza tym uboga werbalizacja przeżyć emocjonalnych utrudnia efektywną komunikację $\mathrm{w}$ relacjach interpersonalnych, także z własnymi dziećmi. Skutkować to może jak wynika z cytowanych badań stosowaniem nieadaptacyjnych strategii radzenia sobie $\mathrm{w}$ sytuacjach stresowych. Jedną z podstawowych jest podejmowanie strategii radzenia sobie skoncentrowanych na emocjach. Otrzymane rezultaty $\mathrm{w}$ pełni to potwierdzają. Wychowywanie się $\mathrm{w}$ systemie, gdzie ważne jest podporządkowywanie się wymaganiom i oczekiwaniom rodziców, w którym istnieje konieczność nieustannego tłumienia potrzeb, pragnień i emocji może skutkować tendencją do rozwoju deficytów w zdolności do rejestrowania i przetwarzania sygnałów płynących z ciała. Brak świadomości pobudzenia fizjologicznego oraz kumulacja napięcia psychicznego sprzyja rozwojowi doświadczania afektu negatywnego oraz skłonności do jego przeżywania i/lub tłumienia. Nadmierne wymagania, w wyniku których powstaje emocjonalna i fizyczna separacja zarówno rodziców od dziecka jak i dziecka od rodziców powoduje, że zamiast kooperacji pojawiają się antagonizmy. Obie strony wzajemnie zarażają siebie przeżywaniem silnych emocji negatywnych. Opiekunowie dzieci, którzy wykazują znaczną trudność w wyrażaniu swoich emocji, mają jednocześnie deficyty w zakresie konstruktywnych form radzenia sobie $\mathrm{z}$ emocjami dziecka. W rezultacie doprowadzić to może do nieefektywnego rozpoznawania i odpowiedniego pokierowania emocjonalnym rozwojem dziecka (Bagby, Taylor, 2000).

$\mathrm{Na}$ uwage zasługuje to, że model teoretyczny jest dobrze dopasowany do danych jedynie w odniesieniu do matek. Transmisja stylów więzi może także przyczyniać się do rozwoju aleksytymii, strategii radzenia sobie ze stresem oraz specyficznych wzorów przeżywania rodzicielstwa. Uzyskane rezultaty nie znajdują potwierdzenia $\mathrm{w}$ odniesieniu do ojców. Jak wskazywałam w części teoretycznej wiele przeprowadzonych badań nie potwierdzało zjawiska wypalenia rodzicielskiego u ojców dzieci. Uważam, że nie można przyjąć, że takie zjawisko nie ma miejsca lecz zastanowić się nad tym, że inne czynniki mogą sprzyjać rozwojowi wypalenia rodzicielskiego u ojców. Ich rola w wychowaniu dzieci jest nieco inna. Inne są oczekiwania społeczno-kulturowe. Warto temu zagadnieniu poświecić nowe opracowanie i badania.

\section{Wnioski}

Istotnym deficytem $\mathrm{w}$ przypadku aleksytymii jest brak zdolności do modulacji procesów afektywnych przez procesy poznawcze, co wyraża się w zaburzeniach 
doznawania, interpretacji i regulacji emocjonalnej. Osoby aleksytymiczne w większym stopniu niż osoby o niskim natężeniu tej cechy $w$ sytuacjach stresowych stosują nieadaptacyjne strategie regulacji afektu, takie jak między innymi tłumienie emocji. W konsekwencji odczuwają silniejsze pobudzenie psychofizjologiczne oraz nie rejestrują zmian w doświadczaniu negatywnego afektu. Rzadziej natomiast wykorzystują adaptacyjne strategie regulacji emocji, takie jak na przykład przeformułowanie poznawcze (Swart et al., 2009). Aleksytymia jak wynika z badania stanowiąc inwazyjną strategię obrony przed sytuacjami wysokobodźcowymi staje się tym samym czynnikiem ryzyka rozwoju wypalenia rodzicielskiego. Blokując procesy identyfikacji oraz werbalizacji emocji sprawia, że język nie służy do zmiany siebie i innych, gdyż komunikacja jest zaburzona lub zniekształcona. Trudno o porozumienie, kiedy brak jest wspólnych znaczeń i trafnego wzajemnego rozumienia. Procesy takie mogą odgrywać ważną rolę w powstawaniu różnych rodzajów zaburzeń psychicznych, w tym skłonności do wypalenia rodzicielskiego wobec własnych dzieci. Dzieci w kontakcie z rodzicem nie potrafiącym się do nich dostroić odczuwać muszą stres i niepokój, tak jak jest w przypadku więzi lękowych. Rodzic nie potrafiąc dostroić się do własnych dzieci także przezywa dyskomfort i ma poczucie własnej nieporadności $\mathrm{w}$ relacji z dzieckiem. Mechanizm ten powtarzany wiele tysięcy razy staje się wyzwalaczem negatywnych emocji, przemęczenia i w końcu depresji. Im dłużej utrzymuje się taki stan tym silniejsze objawy przemęczenia i wypalenia.

\section{Ograniczenia}

Przeprowadzone badanie, jest klasycznym badaniem korelacyjnym, gdzie zgodnie z modelem teoretycznym przewiduje się określone związki i zależności między zmiennymi. W opisanym badaniu otrzymano rezultaty wskazujące na umiarkowaną istotność badanych zmiennych. Warto także poszukać innych czynników mogących wiązać się ze skłonnością do wypalenia rodzicielskiego np. cech osobowości i jej związków z aleksytymią. Poza tym $\mathrm{w}$ badanej grupie nieznaczna była przewaga mężczyzn. Wprawdzie nie stwierdzono istotnych różnić między płciami w poszczególnych testach, jednakże to kobiety częściej sprawują opiekę nad własnymi dziećmi i jak wynika z wcześniejszych badań częściej doświadczają syndromu wypalenia rodzicielskiego. W następnym projekcie warto kontrolować dobór osób do badania tak, aby w pełni zrównoważyć płeć lub też porównać poziom wypalenia rodzicielskiego wśród kobiet i mężczyzn. Powyższe ograniczenia nie zmieniają jednakże zasadniczego trendu jaki uzyskano analizując wyniki: im wyższa niekonsekwencja i wymagania ze strony matki tym wyższy poziom depresji, aleksytymii oraz większa częstotliwość podejmowania strategii radzenia sobie ze stresem skoncentrowanych na emocjach, skutkując $\mathrm{w}$ rezultacie wyższym poziomem wypalenia rodzicielskiego wobec własnych dzieci. 


\section{Bibliografia:}

Ainsworth, M.S. (1989). Attachments beyond infancy, American Psychologist, 4 (44), 709-716.

Alarcon, G., Eschleman, K.J., Bowling, N.A. (2009). Relationships between personality variables and burnout: A meta-analysis, Work \& stress, 23, 244-263.

Avagianou, P.A., Zafiropoulou, M. (2008). Parental bonding and depression: personality as a mediating factor, International Journal of Adolescent Medicine and Health, 3 (20), 261269.

Bagby, M., Taylor, G.J. (2000). An overview of the alexithymia construct, (in:) R. Bar- On, J.D. Parker (eds.), The Handbook of Emotional Intelligence, 263-276, Sun Francisco: JosseyBass.

Basaran, A., Karadavut, K.I., Uneri, S., O., Balbaloglu, O., Atasoy, N. (2013). The effect of having a children with cerebral palsy on quality of life, burn-out, depression and anxiety scores: a comparative study, European Journal of Physical and Rehabilitation Medicine, 49, 815-822.

Bowlby, J. (1973). Attachment and loss: Vol. 2. Separation: Anxiety and anger, London Hogarth Press.

Enns, M.W., Cox, B.J., Clara, I. (2002). Parental bonding and adult psychopathology results from the US national co- morbidity survey, Psychological Medicine, 32, 997-1008.

Gillath, O., \& Shaver, P.R. (2007). Effects of attachment style and relationship context on selection among relational strategies. Journal of Research in Personality, 4 (41), 968-976.

Hayes, A.F. (2018). Introduction to mediation, moderation and conditional process analysis: A regression - based approach, New York. NY: Guilford Press.

Jones, J.D., Brett, B.E., Ehrlich, K.B., Lejuez, C.W., Cassidy, J. (2014). Maternal attachment style and responses to adolescents' negative emotions: the mediating role of maternal emotion regulation, Parenting: Science and Practice, 3-4 (14), 235-257.

Lazarus, R.S., Folkman, S. (1984). Stres, Appraisal and Coping. New York, NY: Springer.

Łojek, E., \& Stańczak, J. (2019). Inwentarz Depresji Becka - drugie wydanie (Beck Depression Inventory - second edition; BDI-II). Warszawa: Pracownia Testów Psychologicznych.

Lebert-Charron, A., Dorard, G., Boujut, E., Wendland, J. (2018). Maternal Burnout Syndrom: Contextual and Psychological Associated Factors, Frontiers in Psychology, 9, doi: https:// doi.org/10.3389/fpsyg.2018.00885.

Liberska, H., Suwalska, H. (2011). Styl przywiązania a relacje partnerskie we wczesnej dorosłości, Psychologia Rozwojowa, 1 (16), 25-39.

Masoumeh, M., Alavinezhad, R. (2016). Relationship of Alexithymia to Adult Attachment Styles and Self-Esteem among College Students, Journal of Psychiatry and Psychiatric Disorders, 1 (1), 6-14. 
Mikolajczak, M., Raes, M.E., Avalosse, H., and Roskam, I. (2017). Exhausted parents: sociodemographic, child-related, parent-related, parenting and family functioning correlates of parental burnout, Journal of Child and Family Studies, 27, 602-614, doi: https://doi.org/10.1007/s10826-017-0892-4.

Mikolajczak, M., Raes, M.E., Avalosse, H., and Roskam, I. (2018). Exhausted parents: sociodemographic, child-related, parent-related, parenting and family functioning correlates of parental burnout, Journal of Child and Family Studies, 27, 602-614, doi: https://doi.org/10.1007/s10826-017-0892-4.

Mikolajczak, M., Roskam, I. (2018). A Theoretical and Clinical Framework for Parental Burnout: The Balance Between Risks and Resources $\left(\mathrm{BR}^{2}\right)$, Frontiers in Psychology, 9, doi: https://doi.org/10.3389/fpsyg.2018.00886.

Najmi, B., Heidari, Z., Feizi, A., Hovsepian, S., Momeni, F., Masood Azhar, S. M. (2017). Do psychological characteristic of mothers predict parenting stress? A cross-sectional study among mothers of children with different disabilities, Archives of Psychiatric Nursing, 32, 396-402. doi:10.1016/j.apnu.2017.12.004.

Parker, J.D., Bagby, R.M., Taylor, G.J., Endler, N.S., Schmitz, P. (1993). Factorial validity of the 20-item Toronto Alexithymia Scale, European Journal of Personality, 4 (7), 221-232.

Picardi, A., Toni, A., Caroppo, E. (2005). Stability of Alexithymia and Its Rela- tionships with the 'Big Five' Factors, Temperament, Character, and Attachment Style, Psychotherapy and Psychosomatics, 74, 371-378.

Pines, A., Aronson, E. (1988). Career burnout: Causes and cures, New York: Free Press.

Plopa, M. (2008), Kwestionariusz Retrospektywnej Oceny Postaw Rodziców (KPR-Roc). Podręcznik, Warszawa: Wydawnictwo Vizja PRESS \& IT.

Riva, R., Forinder, U., Arvidson, J., Mellgren, K., Toporski, J., Winiarski, J. et. Al. (2014). Patterns of psychological responses in parents of children, Psychooncology, 23, 13071313, doi: 10.1002/ pon.3567.

Roskam, I., Brianda, M. E., Mikolajczak, M., (2018). A Step Forward in the Conceptualization and Measurement of Parental Burnout: The Parental Burnout Assessment (PBA), Frontiers in Psychology, 9, doi: https://doi.org/10.3389/fpsyg.2018.00758.

Roskam, I., Raes, M.E., and Mikolajczak, M. (2017). Exhausted parents: development and preliminary validation of the Parental Burnout Inventory, Frontiers in Psychology, 8, doi: https:// doi.org/10.3389/fpsyg.2017.00163.

Smith, K.H., Adams, S., Symons, D.K. (2015). Adult attachment style and caregiver attitudes after raising a virtual child, Journal of Social and Personal Relationships, doi: https://doi.org/10.1177/0265407515616710.

Szczepaniak, P., Strelau, J., Wrześniewski, K. (1996). Diagnoza stylów radzenia sobie ze stresem za pomocą polskiej wersji kwestionariusza CISS Endlera i Parkera, Przegląd Psychologiczny, 39, 187-210. 
Szczygieł, D., Sekulowicz, M., Kwiatkowski, P., Roskam, I., \& Mikolajczak, M. (2020).

Validation of the Polish version of the Parental Burnout Assessment (PBA), New

Directions for Child and Adolescent Development, doi:

https://doi.org/10.1002/cad.20385.

Ścigała, D.K., Zdankiewicz-Ścigała, E., Bedyńska, S., \& Kokoszka, A. (2020). Psychometric properties and configural invariance of the polish-language version of the 20-item toronto alexithymia scale in non-clinical and alcohol addict persons, Frontiers in Psychology, 11, doi: https:// doi.org/10.3389/fpsyg.2020.01241.

Unal, G. (2004). Evaluation of avoidance, alexithymia and self-esteem in a group of university youth, Journal of Clinical Psychiatry, 7, 215-222.

Van Bakel, H.J.A., Van Engen, M.L., Peters, P. (2018). Validity of the Parental Burnout Inventory Among Dutch Employees, Frontiers in Psychology, 9, doi: https:// doi.org/10.3389/fpsyg.2018.00697.

Varghese, R.T., Venkatesan, S., (2013). A Comparative Study of Maternal Burnout in Autism and Hearing Impairment, International Journal of Psychology and Psychiatry, 1, doi: https://doi.org/10.5958/j.2320-6233.1.2.016.

Zdankiewicz-Ścigała, E., Sikora, J., Ścigała, D. (2018). Postawy rodzicielskie a skłonność do impulsywnej agresji. Mediacyjna rola aleksytymii, Psychologia Wychowawcza, 14, 134154, doi: https:/ / doi.org/10.5604/01.3001.0012.8286. 